\title{
ANALYSIS OF INTERNATIONAL EXPERIENCE OF MANAGEMENT OF MULTI-APARTMENT BUILDINGS
}

\author{
Irina Vanyan ${ }^{1}$ \\ National University of Architecture and Construction of Armenia (NUACA)
}

\begin{abstract}
The article is devoted to the analysis of the international practice of managing multi-apartment buildings to develop recommendations for ensuring effective management and maintenance of the housing stock in Armenia. The developments implemented by the expert group of the NUACA within the project funded by UNDP-GCF with the support of UNDP in 2018-2019 are used in the article. The recommendations for effective housing stock management and maintenance in Armenia are presented in the article based on the desk review and critical analysis of available sources reflecting the experience of numerous countries, particularly the USA, France, Canada, the Netherlands, Germany, Sweden, Switzerland, Poland, Estonia, etc.
\end{abstract}

Keywords: housing management, housing maintenance, owners' association

DOI: $10.17512 /$ znpcz.2020.3.07

\section{Introduction}

From November 2018 to July 2019, the group of experts of the National University of Architecture and Construction of Armenia (NUACA) implemented the project on Development of Rules for Maintenance, Enhancement of Stability, Energy Efficiency Improvement and Operation of Multi-Apartment Buildings (hereinafter "project") funded by the UNDP-GCF project on "De-risking and Scaling-up Investment in Energy Efficient Building Retrofits" with the support of the United Nations Development Program in Armenia. Within this project, numerous works were carried out by the expert group under the requirements of the Term of Reference. Particularly, the following work has been done: review and analysis of legislative framework regulating the processes of appropriate management and maintenance of multi-apartment buildings, analysis of domain and international experience of multiapartment buildings management and maintenance, development of the draft of management and maintenance rules for multi-apartment buildings, recommendations for effective management of multi-apartment buildings in the Republic of Armenia, etc. This article refers only to that part (carried out by the author) of the above-mentioned project regarding the analysis of the international experience of management and maintenance of multi-apartment buildings.

\footnotetext{
${ }^{1}$ Irina Vanyan - Associate Professor, PhD in Economics, irinavanyan@ gmail.com, ORCID: 0000-0002-0310-4759
} 


\section{Analysis of international approaches to multi-apartment buildings management}

Effective organization of management processes for the maintenance and efficient operation of multi-apartment buildings certainly requires the application of appropriate rules, which usually prescribe standards for the maintenance and operation of multi-apartment buildings, as well as the appropriate activities related to the management of multi-apartment buildings. Such standards set out a system of concepts for all those who are concerned with the maintenance and operation of the commonuse property of the multi-apartment building.

The analysis of the available literature and practice in this area allowed to identify and analyze the experience of several countries in the management of multi-apartment buildings with applying standards for the appropriate maintenance and operation of multi-apartment buildings. On the basis of the analysis, it became possible to propose a draft of similar rules applicable to the conditions of the multi-apartment housing stock in Armenia.

By analyzing the international experience in managing multi-apartment buildings, it can be said that the most common practice of managing residential buildings in foreign countries is the creation of associations (condominiums) of building owners, in which the owners make decisions, and decision execution is entrusted to the managing organization (manager) on a contractual basis. However, there are other types of homeowners' associations as well, such as housing cooperatives (in the US, Canada), syndicates (in France), housing joint-stock companies (in Finland), homeowners' associations, associations, unions (in Germany, Sweden) or home-building cooperatives (in Russian Federation), unions of co-owners of multi-apartment buildings (in Ukraine), etc.

The creation of owners' associations (condominiums) in a multi-apartment building is mandatory by law in Norway, Denmark, Germany, the Netherlands, Switzerland, Poland, Hungary and the Czech Republic. Owners' associations in Slovakia, Romania, Bulgaria, Estonia, Latvia, Lithuania, Belarus, Moldova are organized on a voluntary basis (Gentsler 2008, pp. 15-18; Prokofiev, Maiseev, Egorov 2015, pp. 303-318; Bovikina, Kovaleva 2014, pp. 58-62).

In Europe, Asia and America, the term "condominium" is used to mean a single complex of real estate, including a plot with a clear boundary and a residential building that is allocated there, residential and non-residential structures of which are owned by citizens or by legal entities, and common use property is their common share ownership (Prokofiev, Maiseev, Egorov 2015, pp. 303-318).

In the above-mentioned countries, the legislation lays down strict requirements regarding the obligations of owners in multi-apartment buildings. In these countries, owners do not consider the maintenance of their buildings as a burden, as proper servicing of residential buildings leads to real and obvious results (Bayandina 2015).

In a number of countries (France, the Netherlands, the USA, Canada, Poland, Czech Republic, Mexico, etc.) housing management is considered a type of business. The manager or manager company shall be remunerated by the owners for the proper execution of the maintenance and operation of the residential building. However, if 
the residential building does not meet the requirements of safety and quality standards, then all the owners living in the building are equally responsible to the public supervision bodies (Bayandina 2015).

The experience of Poland is also interesting. Poland was one of the first countries of the former socialist block which started reforms in the field of housing and communal services by creating a joint-stock company with 100 per cent state or city capital. All types of utilities were merged into a single company. All economic, technological processes are carried out by the holding. The main course taken by Poland is the provision of quality services and ensuring the reliability of the operation of all facilities. In the field of housing and communal services in Poland, there are suppliers of various forms of ownership. Thus, Krakow Municipal Holding includes energy, water utilities, and municipal transport enterprises. At the same time, $100 \%$ of the holding's shares belong to the Commune (City Hall) of Krakow, which manages cash flows, production, and controls. Despite the fact that the holding is a joint-stock company, the authorities in Krakow do not even plan to sell shares. At the same time, in the market of services such as cleaning, garbage removal, and maintenance of housing in terms of repair - there are many private owners. In Poland, there is no such thing as mass non-payments; problems of non-payment for services do not arise at all. A system of subsidies, benefits, tariffs and loans has been operating there for a long time.

The management of multi-apartment buildings and the provision of housing and communal services is an international theme that unites many countries and is governed by fairly similar concepts. However, due to objective circumstances, each country has its peculiarities, nuances, positive or negative experiences.

The results of the analysis of some existing international best practices of residential buildings management with the purpose to provide appropriate maintenance, improvement of reliability, energy efficiency of the residential building are presented in Table 1 below.

Table 1. Results of the analysis of some existing international best practices in residential buildings management

\begin{tabular}{|l|l|}
\hline Country & \multicolumn{1}{c|}{$\begin{array}{c}\text { Main effective (from the perspective of application in Armenia) } \\
\text { features of management of residential buildings }\end{array}$} \\
\hline USA & $\begin{array}{l}\text { In the United States, there are influential associations of private property } \\
\text { owners who have the authority to develop technical regulations and guidelines } \\
\text { for building maintenance and operation and to impose appropriate penalties in } \\
\text { case of non-compliance to the requirements. }\end{array}$ \\
\hline France & $\begin{array}{l}\text { Most notable is the attempt to apply mandatory rules for the preservation } \\
\text { and operation of co-owned territories established by law in France. It is } \\
\text { proposed to provide general rules of residence for each building in Armenia, } \\
\text { which will include both the requirements related to the entire building as } \\
\text { well as the requirements for servicing and operating a separate apartment. }\end{array}$ \\
\hline Germany & $\begin{array}{l}\text { German experience clearly shows that effective management and maintenance } \\
\text { of the housing sector largely depends on the degree of participation of the } \\
\text { community's population in management. In this regard, one of the ways to }\end{array}$ \\
\hline
\end{tabular}




\begin{tabular}{|c|c|}
\hline Country & $\begin{array}{l}\text { Main effective (from the perspective of application in Armenia) } \\
\text { features of management of residential buildings }\end{array}$ \\
\hline & $\begin{array}{l}\text { improve the management of residential buildings in Armenia should be to } \\
\text { expand and strengthen participatory residential building management. }\end{array}$ \\
\hline Sweden & $\begin{array}{l}\text { The regional rent tribunal (Arbitration Court) is a type of court in Sweden } \\
\text { that can assist in cases where there is a conflict between the tenant and the } \\
\text { landlord (owner). The people apply to the Swedish Tenants Union or the } \\
\text { Regional Tenancy Tribunal in cases when a conflict situation can occur } \\
\text { regarding lease, renting, things the tenant is allowed to do at home, rights } \\
\text { of the tenant, when the apartment has deficiencies, etc. The experience of } \\
\text { arbitration tribunals dealing with housing disputes may also be applicable } \\
\text { in Armenia taking into account how many problems exist currently in the } \\
\text { housing sector of the country. }\end{array}$ \\
\hline Estonia & $\begin{array}{l}\text { The key institutional structure in Estonia that plays an active role in the } \\
\text { housing sector is the Fund of Credit and Export Guarantee (KredEx). The } \\
\text { Fund was established in } 2001 \text { by the Estonian Ministry of Economic Af- } \\
\text { fairs and Telecommunications and aims to: } \\
\text { - improve the financing of small and medium enterprises; } \\
\text { - reduce the risks associated with the credit of export; } \\
\text { - promote housing construction and the improvement of existing housing } \\
\text { stock; } \\
\text { - promote energy efficiency of buildings. } \\
\text { KredEx was created by the merger of three off-budget multifunctional } \\
\text { guarantee agencies. KredEx's activities are considered as the best way to } \\
\text { radically transform the problems of multi-apartment housing in Armenia. } \\
\text { In } 2000 \text {, the Estonian Association of Property Managers and Service Pro- } \\
\text { viders, with the participation of specialists from the Technical University, } \\
\text { developed a "Real Estate Maintenance Standard" (hereinafter "the Stand- } \\
\text { ard"), which was considered a document summarizing best practices in } \\
\text { management and maintenance of the real estate } \\
\text { This Standard, developed by experts, was highly praised by the govern- } \\
\text { ment and approved by state registration as Estonian Standard EVS } 807- \\
\text { 2001 - "Real Estate Maintenance Measures". The new version of the } \\
\text { Standard was published in } 2004 \text { (Standard EVS 807-2004). This Standard } \\
\text { was renamed to "Facility Services. Facilities Management Services Provi- } \\
\text { sion (EVS } 807-2010 \text { ) and republished in 2010. The latest version of the } \\
\text { Standard was published in } 2016 \text { under the name "Management and Ser- } \\
\text { vicing of objects" (EVS 807-2016). } \\
\text { The purpose of developing the Estonian Standard is to identify and de- } \\
\text { scribe the essence of multi-apartment building management and mainte- } \\
\text { nance based on best practices. This Standard is a discretionary document } \\
\text { and is used on a voluntary basis. }\end{array}$ \\
\hline
\end{tabular}

Source: Autor's own elaboration 


\section{Conclusions}

As a result of desk review and critical analysis of available sources reflecting the experience of numerous countries the following recommendations have been made for effective housing management and maintenance:

- The United States experience in the development and application of certain standards for housing maintenance and exploitation can serve as a positive experience for Armenia.

- From the point of view of the application in Armenia, the most notable is the practice of using the defined by law mandatory rules of protection and exploitation of joint property territories in France. It is also proposed to envisage the general rules of residence for each building in Armenia, which will include requirements for the whole building as well as the maintenance and operation requirements for an individual apartment.

- The experience of Germany clearly shows that effective housing management and maintenance depends largely on the level of participatory governance of the community. In this regard, we think that one of the ways to improve the management of buildings in Armenia should be the expansion and strengthening of participatory governance of buildings.

- In the field of housing and utility services provision the use of Swedish experience of housing courts operation, in our view, will contribute to the effective development of the sector and eliminate many problematic issues of this sector in Armenia.

- The Estonian capital repairs funding scheme of multi-apartment buildings can provide a good basis for applying a similar approach in Armenia.

\section{References}

1. Bayandina V. (2015), Foreign Experience of Housing Self-Government and the Possibility of Its Application in Kazakhstan, "Vestnik KazEU", https://articlekz.com/article/1372 4 (accessed: 28.04.2020).

2. Bovikina M., Kovaleva N. (2014), Reform of The Management System in the Field of Housing and Communal Services, "New Technologies", No. 1.

3. Development of Rules for Maintenance, Enhancement of Stability, Energy Efficiency Improvement and Operation of Multi-Apartment Buildings, Final Report, UNDP. Republic of Armenia, Yerevan, 2019. http://www.nature-ic.am/Content/announcements/10612/Final\%20 Report_MAB\%20O\&M\%20Rules_ARM.pdf (accessed: 28.04.2020).

4. Gentsler I. (2008), On Some Issues of Multi-Apartment Building Management, "International Experience: Experience, Analysis, Practice", Vol. 8.

5. Management and Maintenance of Facilities (EVS 807-2016), https://www.evs.ee/en/evs-8072016 (accessed: 05.03.2020).

6. Prokofiev K.Yu., Moiseev V.A., Egorova Yu.A. (2015), Russian and Foreign Experience of Managing Multi-Dwelling Units, "Housing Strategies", Vol. 2(4). 


\section{ANALIZA MIĘDZYNARODOWEGO DOŚWIADCZENIA W ZARZĄDZANIU BUDYNKAMI Z WIELOMA APARTAMENTAMI}

Streszczenie: Artykuł poświęcony jest analizie międzynarodowej praktyki zarządzania budynkami wielomieszkaniowymi w celu opracowania zaleceń dotyczących zapewnienia skutecznego zarządzania i utrzymania zasobów mieszkaniowych w Armenii. W tekście wykorzystano informacje na temat rozwoju dokonanego w ramach projektu realizowanego przez grupę ekspertów NUACA w zakresie inicjatywy finansowanej przez UNDP-GCF przy wsparciu UNDP w latach 2018-2019. Zalecenia dotyczące efektywnego zarządzania zasobami mieszkaniowymi i utrzymania w Armenii zostały przedstawione na podstawie przeglądu dokumentacji i krytycznej analizy dostępnych źródeł odzwierciedlających doświadczenia wielu krajów, w szczególności USA, Francji, Kanady, Holandii, Niemiec, Szwecji, Szwajcarii, Polski, Estonii itp.

Słowa kluczowe: zarządzanie mieszkaniami, utrzymanie mieszkań, stowarzyszenie właścicieli 